DOI: 10.22559/folklor.929

Folklor/edebiyat, cilt:25, say1: 97-1, 2019/1

\title{
Çevrimiçi Pedagojik Formasyon Sertifika Programının Tasarlanması, Uygulanması Ve Değerlendirilmesi
}

\author{
Design, Implementation And Evaluation of the Online Pedagogical Formation Certificate \\ Program
}

Volkan Cantemir*

Müesser Nat ${ }^{* *}$

$\ddot{O} z$

Teknolojik gelişmeler hayatımızı birçok alanda kolaylaştırmıştır. Çok farklı alanlarda hayatımızı etkileyen teknolojinin eğitim alanını da etkilemeyeceği düşünülemez. Eğitim dört tarafı duvarlar ile çevrili bir odada derse katılmak ile sınırlı değildir. Yeni teknolojiler sayesinde eğitimi farklı ortamlarda yapabilmenin önü açılmışır. Teknoloji ve İnternetin yaygın kullanımı ile birlikte çevrimiçi uygulamaların eğitimdeki payı hızla artış göstermektedir. Öğrencilerin bilgiye hızlı bir şekilde, istediği zaman ve istediği yerden ulaşması, coğrafi ve bölgesel engellerin ortadan kalkması öğrencilerin bu tür uzaktan eğitim uygulamalarına yönelmelerini sağlamıştır. Eğitim yönetim sistemi uygulamaları kullanılarak sanal ortamlarda sınıflar yaratılarak derslerin işlendiği öğrencinin ister canlı olarak ister ise daha sonradan tekrar izleyebileceği yenilikçi bir eğitim sistemi olarak görülmektedir. Bu eğitim sistemi bir çok alana entegre edilmesinden sonra pedagojik formasyon eğitimi için de yaygın olarak kullanılmaktadır. Bu gelişen eğitim teknolojileri sayesinde öğretmen olmak isteyen eğitim fakültesi hariç diğer üniversite bölümlerinden mezun olan adaylara uzaktan eğitim programlarıyla pedagojik formasyon sertifikası alma imkanı tanınmıştır. Yapılan benzer çalışmalarda uzaktan eğitim ile gerçekleşen pedagojik formasyon sertifika programına katılan öğretmen adayları için ulaşılmak istenen hedef, amaç, eğitim ve öğretim süreçlerinde ki boyutlar olumlu olduğu gözlenmiştir. Üniversite mezunu ve belirli bir yaşa ulaşmış insanlar artık toplumda kabul görebilmek için birer işe girmiş ve çalışmak durumunda kalmış olabilirler. Dolayısı ile örgün öğretime zamanları olmayabilir. Bu nedenlerden dolayı hem daha kolay erişim sağlayabilmek hem de zamandan tasarruf edebilmek için uzaktan eğitim programlarına ihtiyaç duyulmaktadır. Uzaktan eğitim sistemlerinde ders materyali, öğretmen ve öğrenci arasındaki iletişimi sağlayacak platformlara ihtiyaç vardır. Bu platformlardan biri de açık kaynak kodlu Moodle sistemidir. Bu çalışmada online pedagojik formasyon eğitimi sertifikası için tasarlanan Moodle eğitim ortamını detaylı bir şekilde açıklayarak öğretmen adaylarının bu sertifika programı çerçevesinde almış oldukları yedi farklı dersin Moodle verilerini analiz etmektedir. Bu sayede öğretmen adaylarının

\footnotetext{
${ }^{*}$ Arş. Gör., Uluslararası Kıbrıs Üniversitesi, Yönetim Bilişim Sistemleri, vcantemir@ciu.edu.tr

${ }^{* *}$ Yrd. Doç. Dr., Uluslararası Kıbrıs Üniversitesi, Yönetim Bilişim Sistemleri Bölümü, mnat@ciu.edu.tr
} 
ders materyallerine hangi formatta, hangi zaman aralıklarında ve hangi sıklıkta ulaştıkları belirlendi. Ek olarak uzaktan eğitim ile moodle sistemi üzerinden ders alan 32 öğretmen adayının moodle eğitim ortamı hakkındaki görüşleri ve değerlendirilmesi anket aracılığı ile toplandı. Bu veriler istatistiksel hesaplamalar yapılarak yorumlandı ve sonuçlar elde edildi. Bu çalı̧̧mada elde edilen bulgular çevrimiçi pedagojik formasyon sertifika programlarının tasarlanması ve etkin kullanımına önemli katkılar sağlamaktadır. Kurumlar bu bulguları göz önünde bulundurarak ilerdeki çevrimiçi eğitim uygulamalarının daha etkin yürütebilirler.

Anahtar sözcükler: çevrimiçi eğitim, uzaktan eğitim, Moodle, pedagojik formasyon

\section{ABSTRACT}

Technological developments have made our life easier in many ways. It is unimaginable that the technology that affects our lives in many different areas will not affect the field of education. Education is not limited to attending classes in a room surrounded by walls. With the help of new technologies, education can occur in various environments. With the widespread use of technology and the Internet, the share of online applications in education is increasing rapidly. It made students to prefer such distance education practices where they can access the information quickly, from any time and place, without geographical and regional obstacles. Classes are created in virtual environments by using educational management systems and it is seen as an innovative education system in which the learner can watch the lecture live or later. This education system is widely used for pedagogical formation education after being integrated into many fields. With these developing educational technologies, candidates who graduated from other university departments except the faculty of education and want to become teachers are granted the pedagogical formation certificate with distance education programs. In the similar studies conducted, it was observed that the target, purpose, education and teaching process dimensions for the prospective teachers who participated in the pedagogical formation certificate program realized by distance education were positive. People who have graduated from university and have reached a certain age may now have to work in order to be accepted in society. Hence, they may not have time for formal training. Therefore, distance education can be a solution to this problem. In distance education, there is a need for platforms to provide lecture materials, communication between teacher and student. One of these platforms is the open source Moodle. In this study, Moodle, designed for online pedagogical training certificate, is explained in detail as a training environment and Moodle data from seven different courses that prospective teachers have taken in the framework of this certification program were analzed. In this way, how, when and how often the teacher candidates accessed the course materials were determined. In addition, 32 teacher candidates' opinions and evaluations about the Moodle training environment were collected through the questionnaire. These data were interpreted by statistical calculations and the results were obtained. Findings from this study provide important contributions to the design and effective use of online pedagogical formation certification programs. Institutions can more effectively pursue future online education practices by taking these findings into account.

Keywords: online education, distance education, Moodle, pedagogical formation 


\section{Giriş}

Teknoloji artık hayatımızın her noktasında var olmaya başlamıştır. Getirdiği kolaylıklar, sunduğu imkânlar sayesinde her yaş topluluğunun ilgi duyduğu ve kullandığı bir alan olmuştur. Bununla birlikte eğitim de teknolojinin en çok kullanım alanlarından biri olmuştur. Öğrenciler artık bilgiye daha fazla kaynaktan, zaman ve yer kıstlaması olmadan ulaşabilmektedir. Eğitimde bilgisayarın kullanılışı 1960 ve 1970'li yıllara dayanmaktadır. Bu yıllarda eğitim ile ilgili uygulamalar geliştirilmeye başlanmıştır. Bu projelerden en önemlileri IBM1500, PLATO ve TICCIT sistemleridir. Florida eyalet üniversitesinde IBM1500 projesi üniversite düzeyinde bilgisayar destekli fizik ve istatistik öğretimi, daha sonra da okuma ve matematik becerilerinin öğrenilmesine dair öğretim yapılmıştır (Ekici \& Yılmaz, 2013). Uzaktan eğitim ise bir süreç olarak işlendiğinde tarihi daha eskilere dayanmaktadır.

\subsection{Uzaktan eğitim}

Teknolojinin hızlı bir şekilde gelişmesiyle uzaktan eğitimde de büyük değişiklikler yaşanmıştır. Dünya'da ve Türkiye'de uzaktan eğitimi evreler halinde incelenecek olursa ilk evre mektupla, ikinci evre radyo ve televizyonla, üçüncü evre canlı telefon ve canlı televizyon yayını ile uzaktan eğitim ve son evre eknek öğrenme modelleri olarak bilinmektedir.

1.Evre, 1700 'lü ylllarda ilk evre olan mektupla eğitim sistemi başlamıştır. 1728 yllında Boston Gazetesi'nde "Steno Dersleri” verileceği belirtilmiş ve bu derslerin uzaktan eğitim aracılı̆̆ ile gerçekleşeceği açıklanmıştır (Kırık, 2014). Uzaktan eğitimi Türkiye'de ise ilk olarak Ankara Üniversitesinde 1956 yllında Hukuk Fakültesi Banka ve Ticaret Hukuku ve Araştırma Enstitüsü başlatmıştır. Bu uygulama ile bankada çalışanlar mektup ile eğitim görmüşlerdir. Milli Eğitim Bakanlığı 1961 yılında Mektupla Öğretim adında bir öğretim merkezi kurmuştur (Ergin, 2010)

2. Evre, radyo ve televizyon kullanımının olduğu çoklu ortam modelini gösterebiliriz. Amerika Birleşik Devletlerinde ilk olarak 1919 yılında eğitim ile ilgili bir radyo istasyonu kurulmuştur. Türkiye'de ise bu süreç 1981 yllında Anadolu Üniversitesi'nin TRT ile birlikte 
çalışarak okul televizyonu yayınına başlamasıyla başlamıştır. 1990 yılında ise Fırat Üniversitesi eğitim amaçlı radyo ve televizyon yayını yapmaya başlamıştır (Yadigar, 2010).

3. Evre, canlı telefon ve canlı televizyon yayını olan Tele öğrenme modeli gösterilebilir. Bu modelde televizyon yayını veya radyo programı canlı olarak yapılmakta öğrenciler yayına telefon ile katılabilmekte ya da e-posta aracılığı ile sorularını sorabilmekteydiler. Türkiye'de bu model ilk olarak 2007 yılında TRT4'te yayınlanan Anadolu üniversitesi açık öğretim fakültesi dersleri olmuştur. Buradaki amaç öğrencileri sınavlara daha iyi hazırlayabilmekti (Tezcan, 2012).

4. Evre, Esnek öğrenme modelidir. Bu model için Internet sayesinde etkileşimli çoklu ortamlar, web tabanlı sayfalar, kullanıcıya otomatik cevaplar veren sistemler, sanal sinıflar örnek gösterilebilir. Bu modelin öğretim elemanına zamana ve mekâna gerek duymaksızın ders verme imkânı sağlaması birçok üniversitenin de uzaktan eğitim sistemine yönelmesine olanak sağlamıştır (Ipfs, 2014).

Uzaktan eğitimin sisteminin yararlarını maddeler haline getirecek olursak;

- Merkezden tüm dünyaya ayni bilgi gönderilebilir,

- Öğrenciye geri bildirim daha hızlı bir şekilde yapılabilir,

- Zaman sınırı olmadığından öğrenci motivasyonunu daha yüksek tutar,

- Puanlama, değerlendirme objektif olarak daha hızlı yapılır,

- Öğrencinin istediği yerden bilgiyi öğrenmesine olanak tanıdığından, öğrenme mesafesi azaltılır,

- Maddi olarak yüksek sayıda ki öğrencilere ulaştığı zaman, materyal kullanımını azaltacağı için maliyeti düşürür (Dinçer, 2016)

Her alanda kendini gösteren ve sürekli bir gelişim içinde olan uzaktan eğitim sistemleri eğitimin farklı alanlarında da kendini göstermeye başlamıştır. Uzaktan eğitim sistemi geleneksel eğitime alternatif olarak ortaya çıkmıştır. Geleneksel eğitimde bulunan öğretmenöğrenci-sınıf üçgenini çok daha farklı boyutlara taşımayı başarmıştır.

\subsection{Moodle}

Uzaktan eğitimde kullanılan eğitim yazılımlarından en önemlilerinden biri de büyük bir payı elinde bulunduran Moodle sistemidir (Kavak, 2009). Moodle sistemi 222 ülkede kullanılıp 77 ayrı dil desteği sunmaktadır. Toplamda 78 milyondan fazla kayıtlı kullanıcısı 
bulanmaktadır(moodlenews, 2015). Moodle açılımı İngilizce olarak "Modular Object Oriented Dynamic Learning Environment" şeklindedir ve Türkçe karşılığı da "Nesne Yönelimli Dinamik Öğrenme Ortamı” şeklindedir. Moodle, ücretsiz olup açık kaynak kodlu (open source) bir eğitim yönetim sistemidir (Kavak, 2009). Moodle sistemi eğitim sisteminin gelişmesine katkıda bulunmak için başlatılmış bir projedir. Moodle'ı daha detaylı ele alacak olursak bu sistem ilk harfinin açılımda olduğu gibi içinde birçok küçük modül barındırır. Bunlar; ödev modülü, sohbet modülü, veritabanı modülü, forum modülü, sözlük modülü, ders modülü, sınav modülü, anket modülü ve wiki modülüdür (Uçar, Berk, \& Kumtepe, 2015).

Ödev modülünde öğrencilere verilen ödevler öğretmenler tarafindan toplanıp değerlendirmeye alınır. Öğrenciler sadece kendi yükledikleri ödevleri görebilirler diğer ödev yükleyen öğrencilerin ödevlerini göremezler. Öğretmen istediği takdirde ödevlere belli bir süre sınırlaması getirilebilir. Öğretmenler öğrencilerin yükleyeceği dosya boyutlarını dahi belirleyebilirler (Elmas, Doğan, Biroğul, \& Koç, 2008). Sohbet modülü, öğrencilerin aralarında mesajlaşabileceği ve ses kaydı yaparak dahi birbirlerine mesaj göndermelerine de olanak sağlar. Veri tabanı modülü Moodle sistemi kullanıcılarının istedikleri bir konu üzerine veri tabanı oluşturmalarına olanak sağlar. Öğretmen girişi yapan kullanıcılar yapılan bu veri tabanlarını diğer kullanıcılarla paylaşabilir. Veri tabanı üzerinde değişiklere izin verebilir ve eklenecek olan bilgiyle ilgili tarih ve saat bilgilerine kadar değişiklikler gerçekleştirebilir (Ülker, 2015). Forum modülü, Moodle sisteminin en fazla kullanılan parçalarından biridir ve öğretmenler kadar öğrenciler tarafından da kullanılmaktadır. Öğretmen tarafından yeni bir ders açıldığı takdirde otomatik olarak o dersle ilgili bir forum başlığı da açılmış olur. $\mathrm{Bu}$ modül sayesinde öğrenciler istedikleri ders ile ilgili olan forumda o dersle ilgili soru sorabilir dosya veya not paylaşımında bulunabilirler. $\mathrm{Bu}$ forumlara veri girişi sadece öğretmenler tarafından yapılmaktadır. Öğretmenler forumda öğrencilerin yaptıklara yorumlara, sorulara cevap verebilir ve bu şekilde bilgi alış-verişi yapmış olabilirler. Sözlük modülü sadece öğretmen girişi yapılarak kelime eklenebileceği gibi tüm kullanıcılara açık bir şekilde de bırakılabilir. Kullanıcılar tarafından eklenen herhangi bir kelime öğretmen tarafından düzeltilebilir veya uygunsuz bulunduğu takdirde silinebilir. Sözlük modülünde var olan bir kelime ders içerisinde kullanıldığında kelimenin üstüne gelindiğinde sözlük modülündeki karşılığ1 gösterilir (Oğraş, Arı, Ateş, \& Ünal, 2016). Ders modülü öğretmenlerin öğrenciler için oluşturdukları HTML sayfalarına ulaşmalarını sağlar. Bu sayfalar da öğrenciler kendileri için oluşturulan HTML sayfalarında gezinti yapabilirler. En basit haliyle sayfa altılarında bulunan ileri ve geri butonları yardımıyla bir sonraki sayfaya veya bir önceki sayfaya yönelmelerinde yardımcı olur. Bu modül değiştirilebilir bir yapıdadır öğrencinin kendi 
ilerleyeceği veya seçim yaparak ilerleyeceği bir tasarım sunulabilinir. Ders sayfası öğretmenin ihtiyaçları doğrultusunda yapılandırılabilinir. Öğretmenler de istedikleri takdirde dersleri şifreleyebilir ve bu şekilde kayıt olan öğrencilerin kontrolünü yapmış olabilirler (Pala, \& Doğan, 2009). Sinav modülü, öğretmenlerin sistem üzerinden öğrencilere sınav yapmasına olanak sağlar. Sınav soruları için çoktan seçmeli, doğru-yanlış veya açık uçlu sorular gibi farklı olasılıklar seçilebilir. Öğretmen daha önce yapmış olduğu sınavlarda ki soru örneklerini saklayabilir isterse tekrar kullanabilir veya farklı tarzda yeni sorular hazırlayabilir. Sınav için belli bir tarih saat aralığı seçilebileceği gibi bir sınav için birden fazla deneme hakkı da tanınabilir (İnner, 2014). Anket modülü, öğretmenler tarafından ders ile ilgili öğrencilerin fikirlerini almakta kullanacakları bir anket hazırlamalarına olanak sağlamaktadır. Öğrencilerin anket sorularına verecekleri cevaplar dâhilinde öğretmenler derslerini daha etkili olabilecekleri bir şekilde hazırlayabilirler. Wiki modülü kullanıcıların herhangi bir programlama bilgisi olmadan birlikte kullanabilecekleri web dokümanları oluşturmalarına olanak sağlar. (Aydın, 2014)

\subsection{Pedagojik formasyon}

Eğitim sistemin en önemli parçalarından birisi öğretmenlerdir. Öğretmenlerin mesleklerinde başarılı olabilmeleri için nitelikli, konu bilgisi, alan bilgisi ve pedagojik alan bilgisine sahip olmaları gerekmektedir. Pedagojik alan bilgisi bir alan uzmanı ile alan öğretmenini birbirinden ayırmaktadır. Pedagojik Formasyon eğitimi öğrenme ve öğretme konularına yönelik gerekli bilgileri içermektedir (Ayas \& Sözbilir, 2015).

Öğretmen ihtiyacının karşılanması ülkemizde eğitim fakültesi mezunu öğrenciler tarafından karşılanmaktaydı (Aydın, 1998). Yükseköğretim Kurulunun 28.01.2010 tarihinde aldığg bir kararla 2010 - 2011 eğitim öğretim yılında yapılan bir değişiklik ile eğitim fakültesi mezunu olmayan öğrencilerin, hangi fakülteden mezun olduğuna bakılmaksızın, öğretmenlik yapabilmeleri için pedagojik formasyon programına katılmalarına olanak sağlanmıştır. Uzaktan eğitim ile de uygulanabilen bu formasyon eğitimi için lisans mezunu adayların not ortalamasının 2.5 üzeri olması şartı aranmaktadır (Akdemir, 2013).

Dersler genel olarak aynıdır. 1. dönem ve 2. dönem dersleri olarak verilir. 1. dönem dersleri uzaktan eğitim ile verilmektedir.

Uzaktan eğitim ile verilen teorik dersler aşağıdaki gibi olup toplam 14 krediden oluşmaktadır (Yükseköğretim Kurulu, 2015). 
- Eğitim bilimlerine giriş

- Öğretim ilke ve yöntemleri

- Eğitimde ölçme ve değerlendirme

- Eğitim psikolojisi

- Sinıf yönetimi

- Seçmeli ders 1

- Seçmeli ders 2

\section{2. Çalışmanın amacı}

Bu çalışmada uzaktan eğitim öğrenme-öğretme süreçlerinde kullanılan;

- Açık kaynak kodlu Moodle sistemi ile uzaktan eğitim programının tasarlanması

- Öğretmen adaylarının uzaktan eğitim ile verilen pedagojik formasyon derslerine erişimlerini incelemek

- Öğretmen adaylarının uzaktan eğitim ile ilgili görüşlerini değerlendirmek

\section{Araştırma yöntemi}

Pedagojik formasyon ders materyalleri öğrencilere iki farklı formatta sunulmuştur: sunu ve video. Her dersin videosu özel bir stüdyoda profesyonel kameralar ile kaydedilmiş ve Articulate Storyline yazılımı ile düzenlenmiştir. $\mathrm{Bu}$ yazılım ile düzenlenen videolarda öğrencilere videoları izlerken aynı anda hem dersi anlatan öğretim elemanını hem de arka ekranda ders notlarını okuma olanağı sağlanmıştır. Her ders için dersin notlarına ve öğretim elemanına bağlı olarak en az 3 en fazla 10 video çekimi ve düzenlemesi yapılmıştır. Videolar sırası ile ders konularına göre haftalık olarak yayınlanmıştır. Ek olarak videolarla birlikte sunular da öğrencilerle paylaşılmıştır. Ayrıca, öğretmen adaylarının ve öğretim elemanlarının iletişim içinde olabilmeleri için Moodle sistemi üzerinden mesajlaşma imkanı da tanınmıştır. Böylece, bu sistem ve dijital içerikler sayesinde öğretmen adaylarına öğrenimleri esnasında mekan ve zaman açısından esneklik sağlanmıştır.

$\mathrm{Bu}$ çalışmada uzaktan eğitim ile verilen pedagojik formasyonda ki 7 dersin Moodle üzerindeki sunu ve videolarına ait veriler analiz edilmiştir. Bu derslerle ilgili öğrencilerin sisteme girişleri, ders materyallerini içeren Moodle sayfasına erişimleri, video ve sunuların izlenme sayıları, izlenme saatleri ve izlenme tarihleri ile ilgili tüm veriler alınmış, düzenlenmiş ve analiz edilmiştir. Bunun yanında, Moodle üzerinden eğitim görmekte olan 32 öğretmen adayına çevrimiçi öğretim ortamı ve ders materyalleri hakkındaki görüşlerini 
öğrenmek için 6 tane 5'li likert ölçekli soru içeren bir anket uygulanmıştır ve toplanan veriler değerlendirilmiştir.

\section{Veri analizi}

Moodle sisteminden alınan veriler doğrultusunda 7 farklı ders için Moodle sistemi üzerinden yayınlanan sunular ve videoların gün içerisinde hangi saat aralıklarında ve kaç defa görüntülendiği analiz edilip grafikle gösterilmiştir.

Dersler:

Ders 1: bilgisayar destekli öğretim

Ders 2: eğitim bilimine giriş

Ders 3: eğitim psikolojisi

Ders 4: eğitim tarihi

Ders 5: eğitimde ölçme ve değerlendirme

Ders 6: öğretim ilke ve yöntemleri

Ders 7: sınıf yönetimi

Saat aralıkları:

05 - 12 arası sabah

12 - 19 arası öğlen

19 - 00 arası akşam

00 - 05 arasi gece

\begin{tabular}{llllllll}
\hline SUNULAR & \multicolumn{10}{l}{} \\
\hline & DERS 1 & DERS 2 & DERS 3 & DERS 4 & DERS 5 & DERS 6 & DERS 7 \\
SLAYT & 7 & 1 & 1 & 2 & 7 & 7 & 1 \\
IZLENME & 737 & 152 & 117 & 270 & 365 & 532 & 112 \\
\hline
\end{tabular}

Tablo 1: Slaytların izlenme verileri

\begin{tabular}{llllllll}
\hline VIDEO & & & & & & & \\
\hline & DERS 1 & DERS 2 & DERS 3 & DERS 4 & DERS 5 & DERS 6 & DERS 7 \\
VIDEO & 6 & 7 & 10 & 6 & 7 & 3 & 5 \\
IZLENME & 565 & 1331 & 431 & 642 & 634 & 518 & 824 \\
\hline
\end{tabular}


Tablo 2: Videoların izlenme verileri

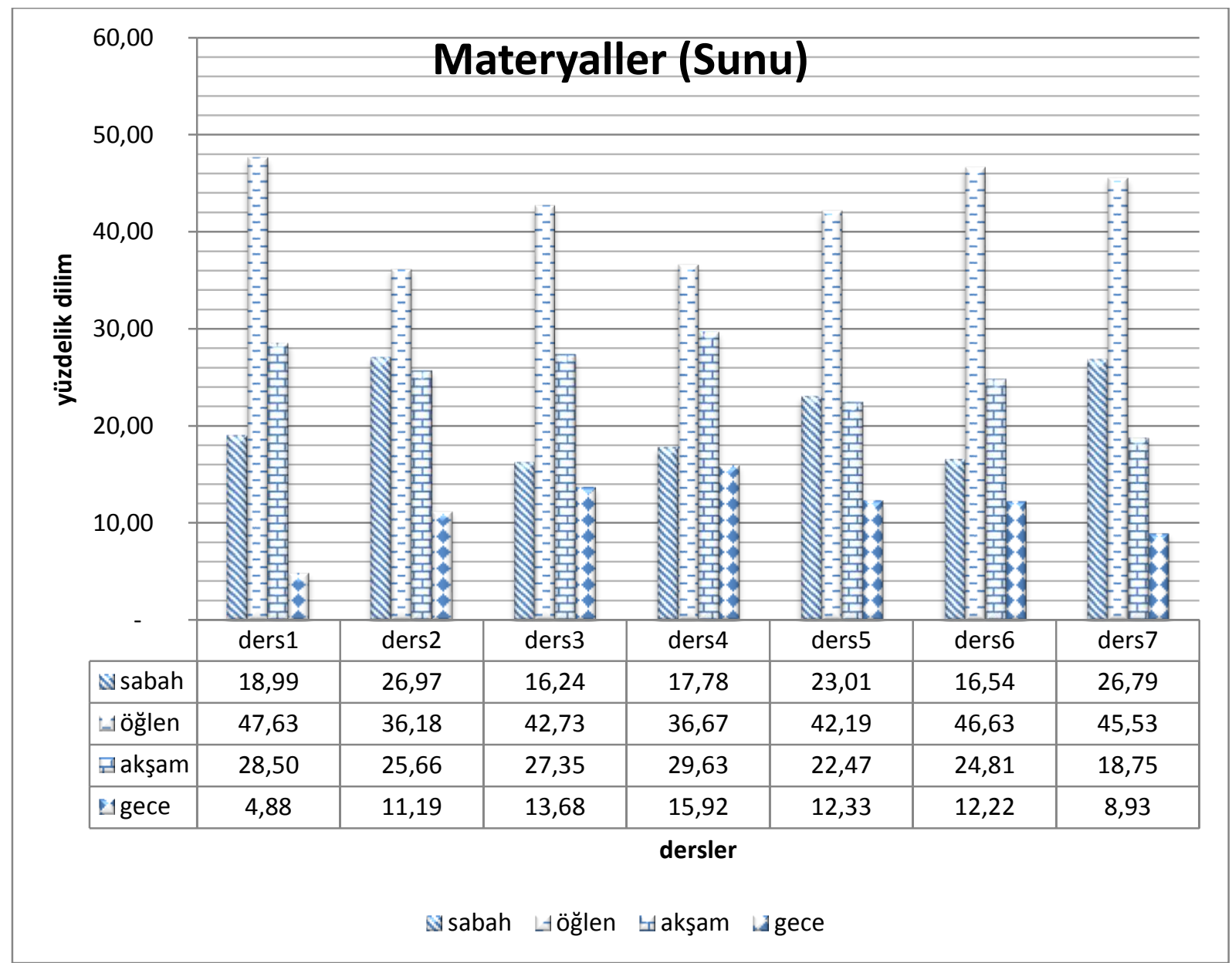

Tablo 3: Slaytların gün içerisindeki izlenme yüzdelikleri

SUNU (PowerPoint); Derslere bakıldığında en fazla izlenme saat aralığı öğlen 12:00 ile 19:00 arası olmuştur. En az izlenme saat aralığ gece 00:00 ile 05:00 arası olmuştur. En fazla izlenen sunu \%47.63 ile ders 1 olmuştur. Ders 1 toplamda izlenme sayısı 737 olmuştur. 


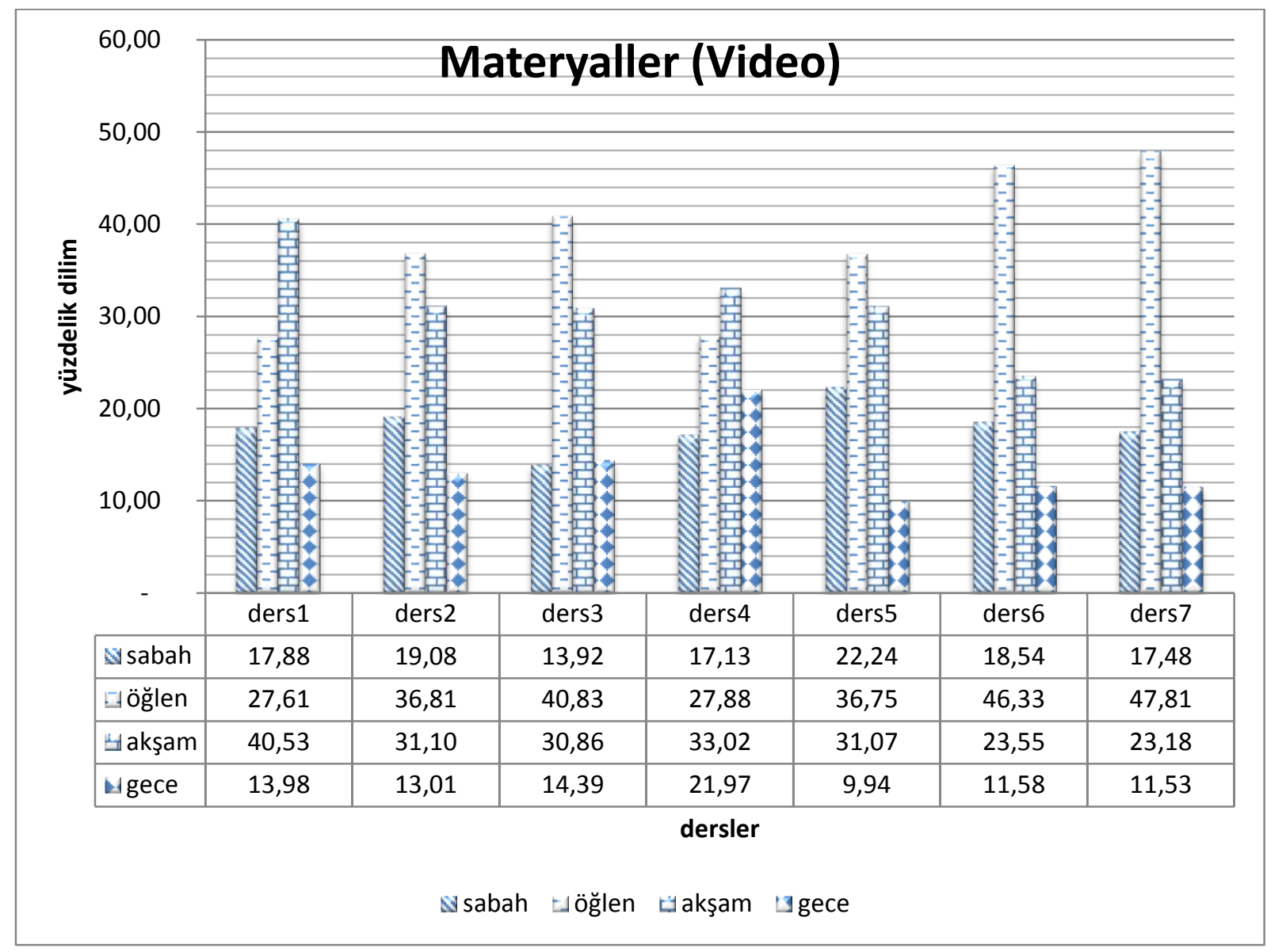

Tablo 4: Videoların gün içerisindeki izlenme yüzdelikleri

Video; Derslere bakıldığında en fazla izlenme saat aralığı öğlen 12:00 ile 19:00 arası olmuştur. En az izlenme saat aralığ1 gece 00:00 ile 05:00 arası olmuştur. En fazla izlenme 1331 izlenme ile ders2 ye aittir. Ders materyallerinde sunu az olduğundan dolayı öğrenciler videoya çok daha fazla ağırlık göstermiştir. 1331 izlemeden sonra en yakın seçenek 824 izleme ile ders 7 de kalmıştır. Ders sunusu ne kadar az olursa öğrencilerin videoya eğilimi o kadar fazla olmuştur.

Saat aralıklarına bakıldığında formasyon alan kişilerin yaş ortalamalarının da yüksek olduğu göz önünde bulundurularak sabah saatleri iş başlangıç saati ve yoğunluk olduğundan öğlen saat aralığı iş çıkışına geldiğinden akşam saat aralığı aile hayatına denk geldiği için ve gece saat aralığı da çalıştıkları için dinlenme zamanı olduğundan Video ve PowerPoint sunularına ayrılan en ideal saat aralığı öğlen saatleri olmuştur ve yüzdelik dilimlere bakıldığında da görülmektedir. 


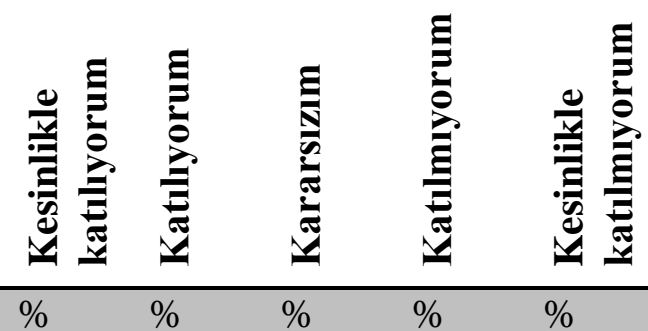

$\begin{array}{llllll}\text { Ders materyalleri konuları öğrenmeme yardımcı oldu } & 22,20 & 27,33 & 19,46 & 9,71 & 21,31\end{array}$

$\begin{array}{llllll}\text { Ders materyalleri genel olarak ilgi çekiciydi } & 15,86 & 24,34 & 20,11 & 16,33 & 23,36\end{array}$

$\begin{array}{llllll}\text { Ders videolarının görsel kalitesinden memnun kaldım } \quad 11,75 & 30,69 & 15,06 & 14,68 & 27,83\end{array}$

$\begin{array}{llllll}\text { Ders videolarının ses kalitesinden memnun kaldım } & 15,96 & 34,31 & 9,14 & 11,43 & 29,16\end{array}$

$\begin{array}{lllllll}\text { Ders videolarını izlerken boyutlarından dolayı } & 16,13 & 26,27 & 17,05 & 13,36 & 27,19\end{array}$ herhangi bir sorun yaşamadım

Sinıf ortamında derse katılmak yerine online ortamda $\quad 24,43 \quad 21,72 \quad 13,06 \quad 13,61 \quad 27,17$ derse katılmayı tercih ederim

\section{Ortalama}

$\begin{array}{lllll}17,72 & 27,44 & 15,65 & 13,19 & 26,00\end{array}$

Tablo 5: Anket soruları \& Yüzdelik dilimler

Yapılan anket sonuçlarına göre; Öğrenciler ders materyallerinden genel olarak memnun olmaktadırlar. Yalnızca 1. 2. 3. ve 4. sorularda kesinlikle katılmıyorum seçeneği yüksek çıkmıştır. Bu yüzden sade bir PowerPoint sunusu veya ders videosu yerine, daha interaktif, teknolojiyi daha etkili bir şekilde kullanıp bunu derse yansıtmak, animasyon, simülasyon ve etkileşime dayalı çeşitli görsellerle bunları geliştirip öğrenciye sunmak daha çok dikkatlerini çekecektir ve daha etkin bir katılım sağlanacaktır. 5. soruda yaşanan sorunlar internet hızı, kullanılan bilgisayar, tablet veya telefondan kaynaklıdır. 6. soruda yüzdelerin birbirine yakın oranda çıkması öğrencilerin hala uzaktan eğitim ve örgün eğitim arasında bir karar vermekte zorlandığg 1 görülmüştür.

\section{Sonuçlar}

Teknolojilerin kullanımı günümüzde her alanda hızla artmaktadır. Eğitimde de bu artış görülmektedir. Pedagojik formasyon eğitimi de artı uzaktan eğitim yoluyla verilebilmektedir. Tuncer \& Tanaş (2010) yaptığı çalışmada içerik bakımından kıyaslama yapıldığında öğrenme ortamında oldukça karamsar bir havanın hakim olduğunu, uzaktan eğitimde kaliteli materyallerin hazırlanması ve sunu, video gibi öğretmen niteliklileri nedeni ile sorun yaşandığını belirtmiştir. Çevrimiçi pedagojik formasyon ile ilgili yapılan önce ki 
araştırmalarda öğrencilerin hazır bulunuşluk seviyeleri, var olan videoların güncellenmeleri, öğrencinin kalıcı öğrenmeyi gerçekleştirebilmesi için materyallerin arttırılması üzerine yapılmıştır. Fakat bu çalışmada uzaktan eğitim ile verilen pedagojik formasyon derslerinin kullanımı incelenmektedir. Bu çalışmanın ilk bulgularında da görüleceği gibi günümüz teknolojileri sayesinde çalışanlar kendilerine en uygun zaman dilimlerinde öğrenimlerini gerçekleştirebiliyor. Bu yenilikçi teknolojiler sayesinde gelen esneklik çalışan insanlara kendilerini geliştirme firsatı sunuyor. Bu bulgular Şeker'in (2016) uzaktan eğitimin çalışan kişilerin uzun vadede kendilerine yeni bilgiler edinmeleri ve kendilerini geliştirmek için kaçamayacakları bir öğrenim şekli olduğunu belirttiği görüşü ile uyuşmaktadır.

Hızla gelişen teknolojilerle birlikte sade bir video veya slayt sunumu yerine daha fazla duyu organına hitap eden materyaller geliştirilerek öğrencilere daha etkili bir eğitim ortamı hazırlayabilmek daha kolay hale gelmiştir. $\mathrm{Bu}$ çalışmanın amaçlarından bir diğeri ise öğretmen adaylarının uzaktan eğitim ile ilgili görüşlerini incelemektir. Elde edilen bulgularda öğrencilerin sınıf ortamı ile sanal ortam arasındaki derse katılım tercihi konusunda kararsız oldukları gözlenmiştir. Bu bulgular, interaktif ve yenilikçi teknolojileri ders materyallerine yansıtmak, animasyon, simülasyon ve etkileşime dayalı çeşitli görsellerle bunları geliştirip öğrenciye sunmak onların daha çok dikkatlerini çekecektir. Örneğin, sanal sınıflar oluşturulup VR-AR teknolojileri uzaktan eğitim için uygulanıp gerçek sınıf ortamına entegre edilebilir. Uzaktan eğitim bu sayede tek düze bir eğitim sistemi olmaktan kurtulacaktır ve uzaktan eğitim derslerine daha etkin bir katılım sağlanabilecektir. İleriki araştırmalarda öğrencilerin teknolojinin daha etkili bir şekilde (interaktif sanal sınıf ortamı, oyunlaştırma yöntemi, vb.) kullanıldığı uzaktan eğitim sınıflarındaki öğrenme eğilimleri ve ilgileri araştırma konusu olabilir. 


\section{Kaynaklar}

Akdemir, A. S. (2013). TÜRKIYE'DE ÖĞRETMEN YETiŞTIRME PROGRAMLARININ TARIHÇESI VE SORUNLARI. Electronic Turkish Studies, 8(12).

Aydın, A. (1998). Eğitim fakültelerinin yeniden yapılandırılması ve öğretmen yetiştirme sorunu. Kuram ve Uygulamada Egitim Yönetimi Dergisi, 4(3), 275-286.

Aydın, Ö. (2014). Yeni Başlayanlar İçin Moodle Genel Bakış. Akademik Bilişim. mersin.

Dinçer, S. (2016, 03 14). BILGISAYAR DESTEKLI EĞiTiM VE UZAKTAN EĞiTiME GENEL BíR BAKIŞ. ADANA, SEYHAN, TÜRKIYE.

Ekici, S., \& Yılmaz, B. (2013). FATiH Projesi Üzerine Bir Değerlendirme. Türk Kütüphaneciliği 27 , $317-$ 339.

Elmas, Ç., Doğan, N., Biroğul, S., \& Koç, M. S. (2008). Moodle Eğitim Yönetim Sistemi Ile Örnek Bir Dersin Uzaktan Eğitim Uygulaması. BILIŞIM TEKNOLOJILERI DERGISI, CILT: 1, SAYI: 2 , 54-56.

Ergin, C. (2010). ILKÖĞRETIM ÖĞRETMENLERININ UZAKTAN EĞiTiME BAKIŞ AÇILARI (Yüksek Lisans Tezi). Yüzüncü Yıl Üniversitesi, Van.

IPFS. (2014, 04 01). https://ipfs.io/ipns/tr.wikipedia-onipfs.org/wiki/Uzaktan_e\%C4\%9Fitimin_tarihsel_geli\%C5\%9Fimi.html adresinden alınmıştır İnner, B. (2014) Harmanlanmiş Öğrenme Ortami Olarak Etkili Moodle Etkinlikleri Kullanim Örneği. Eğitim ve Öğretim Araştırmaları Dergisi-Journal of Research in Education and Teaching, 3(1).

Kavak, M. T. (2009). Dicle Üniversitesi Uzaktan Eğitim Uygulamalarında Eğitim Yönetim Sistemi (Moodle) Kullanımı. Akademik Bilişim'09 - XI. Akademik Bilişim Konferansı Bildirileri, (s. 364). Şanlıurfa.

Kırık, A. M. (2014). Uzaktan eğitimin tarihsel gelişimi ve Türkiye'deki durumu. Marmara iletişim Dergisi , 80-81.

Moodlenews. (2018, 08 10). https://www.moodlenews.com/2015/moodle-statistics-moodle-nowhas-more-than-78-million-users-all-over-the-world-moodleworld-moodle/ adresinden alınmıstır.

Oğraş, R., Arı, M., Ateş, B., \& Ünal, R.(2017). ÇEVRiMiçi TÜRKÇE ÖĞRETiMindE SÖZlÜK KULLANIMI. Ayrıntı Dergisi, 5(50).

Örnekleri, İ. U. (2015). Öğretmen Eğitimcileri, Öğretmenler ve Öğretmen Adayları İçin.

Pala, F., \& Doğan, N. (2009). Nette Öğretmen: Eğitim Yönetim Sistemi. Bilişim Teknolojileri Dergisi, 2(3).

Som, ì., Gürol, M., \& Türkan, A. (2018). PEDAGOJik FORMASYON SERTiFiKA PROGRAMININ DEĞERLENDIRILMESI. Elektronik Sosyal Bilimler Dergisi , 106-108. 
Şeker, S. E. (2016, Şubat 10). Uzaktan Eğitim ve Bilgisayar Mühendisliği. (N. Demir, Röportajı Yapan)

Tezcan, C. (2012). Zihinsel Engelli Çocuklara Web Destekli Uzaktan Eğitim Sistemi Kurulması:

Matematik ve Fen Bilgisi Dersleri Uygulaması(Yüksek Lisans Tezi). Trakya Üniversitesi, Edirne.

Tuncer, M., \& Tanaş, R. (2010). Akademisyenlerin Uzaktan Eğitim Programlarına Yönelik Görüşlerinin Değerlendirilmesi. 4. Uluslararası Bilgisayar ve Öğretim Teknolojileri Sempozyumu (s. 777-782).

Konya: Selçuk Üniversitesi.

Uçar, H., Berk, K., \& Kumtepe, A. T. (2015). Moodle Öğrenme Yönetim Sisteminde Bir Dersin Tasarımı ve Öğretimi: İngilizce Dersi Örneği.

Ülker, D.(2015). ÖĞRENIM YÖNETIM SISTEMLERI ve MOODLE.

Yadigar, G. (2010). UZAKTAN EĞiTiM PROGRAMLARININ ETKINLILIĞININ DEĞERLENDIRILMESi (Yüksek Lisans Tezi). Gazi Üniversitesi, Ankara.

Yükseköğretim Kurulu. (2015, 11 18). 06 15, 2018 tarihinde Yükseköğretim Kurulu:

http://www.yok.gov.tr/web/guest/icerik/-

/journal_content/56_INSTANCE_rEHF8BIsfYRx/10279/7052802 adresinden alındı. 